\title{
O ral health in Brazilian patients with chronic renal disease
}

\author{
Cleber M Souza1 ${ }^{1}$, Ana Paula R Braosi ${ }^{1 a}$, Sônia M Luczyszyn¹, \\ Rafaela W. Casagrande ${ }^{2}$, Roberto Pecoits-Filho ${ }^{1}$, \\ Miguel C Riella ${ }^{2}$, Sérgio A Ignácio ${ }^{1}$, Paula C Trevilatto ${ }^{1 a}$.
}

Background: Poor oral health status may have an impact on the health status of patients with chronic renal failure. Aim: To describe the oral health status of a group of Brazilian patients with chronic renal failure. Material and methods: Retrospective review of the medical records of patients with chronic renal failure, of whom 13 (4.5\%) were in a pre dialysis stage, $158(55 \%)$ were on hemodialysis, 23 (8.4\%) were on peritoneal dialysis and $92(32.1 \%)$ were transplanted. General oral health, presence of dental calculus, and halitosis were recorded. The number of decayed, missed and filled teeth was analyzed by means of DMF-T (Decayed, Missed and Filled Teeth) index. Results: The sample was composed of 152 men (53\%) and 134 women (47\%), aged $42 \pm 13$ years. Oral health status was considered defective in most patients (83\%). Eighty-seven percent had dental calculus and $55 \%$ had halitosis. Transplant patients reported significantly less halitosis (40.2\%) than the rest of the groups. The DMF-T for the whole population was 20.6 and had a positive correlation with age. Conclusions: This group of patients with chronic renal failure presented a poor oral health status. Dental treatment programs for these patients should be implemented to avoid the exposure to dental pathogens (Rev Méd Chile 2008; 136: 741-6).

(Key w ords: Dental health surveys; Kidney failure, chronic; Oral health)

\section{Salud oral en pacientes brasileños con insuficiencia renal crónica}

Introducción: Las alteraciones de la cavidad oral pueden tener impacto en la salud de pacientes con insuficiencia renal crónica. Objetivo: Describir la salud oral de pacientes brasileños con insuficiencia renal crónica. Material y métodos: Revisión retrospectiva de las fichas dentales de pacientes con insuficiencia renal crónica, de los cuales $13(4,5 \%)$ estaban en etapa prediálisis, 158 (55\%) estaban en hemodiálisis, 23 (8,4\%) estaban en peritoneodiálisis y 92 (32,1\%) habían sido trasplantados. Se registró la salud oral general, la presencia de tártaro y halitosis. El número de piezas faltantes y obturadas fue analizado utilizando el índice DMF-T (Decayed, Missed and Filled Teeth o dientes con caries, faltantes y obturados). Resultados: La muestra estaba constituida por 152 hombres y 134 mujeres con una edad promedio de $42 \pm 13$ años. La salud dental general era deficitaria en $83 \%$ y $87 \%$ tenía tártaro. El 55\% tenía halitosis y los pacientes trasplantados tenían este problema con una frecuencia significativamente menor que el resto de los grupos. El índice DMF-T global fue 20,6 y tuvo una correlación positiva con la edad. Conclusiones: La salud oral de estos pacientes con insuficiencia renal crónica es mala. Es importante implementar programas de tratamiento dental para estos pacientes para evitar la exposición a patógenos que pueden causar complicaciones sistémicas.

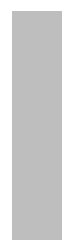

\footnotetext{
Recibido el 20 de julio, 2007. Aceptado el 31 de enero, 2008.

This study was supported by grants from the Araucánia Support Foundation for Scientific and Technological Development of Paraná (grant 5856) and National Counsel of Technological and Scientific Development (CNPq, grant 475770/2004-8).

${ }^{1}$ Pontifical Catholic University of Paraná (PUCPR), Curitiba, Brazil. ${ }^{2}$ Renal, Diabetes and Hypertension Research Center of Pro-Renal Foundation (PRO-RENAL), Curitiba, Brazil.

aDoctor of Dental surgery
}

Corresponding author: Paula Cristina Trevilatto, DDS, PhD. Center for Health and Biological Sciences. Pontifícia Universidade Católica do Paraná (PUCPR). Rua Imaculada Conceição, 1155, Curitiba, PR, 80215-901, Brazil. Phone/Fax: +55 (41) 3271-2618/+55 (41) 3271-1657. E mail: pctrev@yahoo.com.br 
$\mathrm{C}$ hronic kidney disease (CKD) is characterized by a number of systemic complications that result from a profound hidroelectrolytic, metabolic, and immunological imbalance. Despite the improvements in patient care and renal replacement therapy, the impact of CKD on patient's morbidity and mortality is extremely high ${ }^{1}$. Recently, a number of non-traditional risk factors for mortality such as chronic inflammation, oxidative stress and extra-osseous calcification were identified in CKD patients, and the presence of those risk factors was associated with poor outcomes in this population ${ }^{2}$.

Chronic infections appear to be important causes of persistent systemic inflammation and generation of oxidative stress, and patients with CKD are more prone to infections than the general population. Signs of sustained chronic inflammation are present in most CKD patients, but causative mechanisms are yet to be clarified. In addition, abnormalities in the calcium and phosphorus metabolism are highly prevalent in the CKD population, and this mineral imbalance is associated with increased mortality in this group of patients. Strategies to improve CKD patient's outcome will most likely need to focus on the reduction of those risk factors ${ }^{3}$.

Patients presenting CKD are at high risk to develop oral health complications, such as narrowing of pulp chamber ${ }^{4}$, enamel abnormalities ${ }^{5}$, xerostomia ${ }^{6}$, premature tooth loss $^{7}$, increased prevalence of calculus ${ }^{8}$, and periodontal disease ${ }^{9}$, when compared to the general population. Since CKD patients present medical, psychological, and socio-economical characteristics that may predispose to odontological problems, oral health in dialysis and transplant patients has been proposed to be poor, with a potential impact on patient's morbidity, mortality and quality of life ${ }^{6,10}$.

Uremic halitus is a well known clinical characteristic of CKD patients, but comparison between the prevalence of this complication in different forms of renal replacement therapy has not been described until the present. In addition, poor oral hygiene and development of dental calculus are risk factors for periodontal disease, which in turn is a potential cause of sustained systemic inflammation in patients with $\mathrm{CKD}^{11}$. Only a few studies performed in a limited number of patients reported oral health status in CKD patients $7,8,12,13$, and no reports of oral health status performed in a clinic specialized in oral care of CKD patients are available. Moreover, a comparison of oral health status between pre-dialysis, hemodialysis, peritoneal dialysis, and transplant patients has not been described until the present. Therefore, the aim of this study was to report some parameters of oral health status in a population of patients undergoing different modalities of CKD treatment.

\section{MATERIAL AND METHODS}

During the years of 2001-2005, 1,829 CKD patients were treated in the Pro-Renal Foundation Clinics for their CKD in the predialysis (Pre; $n=456$ ), hemodialysis (HD; $n=799$ ), peritoneal dialysis (PD; $n=179$ ), and transplant ( $\mathrm{Tx} ; \mathrm{n}=395)$ clinics. Out of these, about 300 patients attended the dental clinics of the Pro-Renal Foundation, where patients were evaluated and followed up for dental diseases with a focus on CKD. The dental clinics and counts with three dental cabinets, which are used by two dentists, assisted by dental students from local universities.

Two hundred eighty-six (286) patient records were carefully reviewed by dentists, which represent $16 \%$ of the pool of CKD patients treated at the clinics during this period. Out of the patients, 13 (4.5\%) were Pre, 158 (55\%) were HD, 23 (8.4\%) were PD and $92(32.1 \%)$ were Tx patients. The data extracted from the records were: reported main cause of CKD, general medical condition, current medications, and smoking. With regards to the oral status, the following aspects were considered: general oral health condition (good or defective), presence of dental calculus, and halitosis. The number of decayed, missed and filled teeth was computed by means of an index, recognized by DMF-T (Decayed, Missed and Filled Teeth). DMF-T is a numerical representation that indicates the prevalence of tooth decay individually or in a certain population. It is an evaluation method, which is accepted by the international community as an oral health indicator. It is calculated by adding the number of decayed (D), missed $(\mathrm{M})$ and filled $(\mathrm{F})$ teeth $(\mathrm{T})$ which is recommended by the World Health Organization $(\mathrm{WHO})^{14}$. The criteria for classifying calculus were according to WHO recommendations. Calculus was evaluated by observing or noticing its pres- 
ence recovering the dental surface. The study was approved by the Ethical Committee in Research at Pontifícia Universidade Católica do Paraná (PUCPR) (approved under protocol 264/10184).

Values were presented as mean \pm standard deviation. Unpaired Student's t-test was used to investigate the oral health status in relation to caries mean. Analysis of variance (ANOVA) was used to compare differences between different groups. Prevalence of each condition was compared using the chi-square analysis incorporating Yates' correction. Pearson Correlation was used to evaluate association between age and DMF-T. Calculations were performed using the JMP package for Windows (version 7.0, USA) and a p value of less than 0.05 was judged to be significant.

\section{RESULTS}

The study population was composed of 152 men (53\%) and 134 women (47\%), and the mean age was $42 \pm 13$ years. Table 1 shows the baseline clinical parameters of CKD patients according to the modalities of treatment.

The general oral health status was considered defective to most $(233 / 286)$ patients (83\%), regardless the modality of treatment (Figure 1). The
Table 1. M ain characteristics of the study population

\begin{tabular}{|lrr|}
\hline & $\mathrm{n}$ & $(\%)$ \\
\hline Gender & 152 & $(53)$ \\
Males & 134 & $(47)$ \\
Females & & \\
Modalities of treatment & 13 & $(4)$ \\
Pre-dialysis (PRE) & 158 & $(55)$ \\
Hemodialysis (HD) & 23 & $(8)$ \\
Peritoneal dialysis (PD) & 92 & $(33)$ \\
Transplant (Tx) & & \\
Main cause of CKD & 62 & $(22)$ \\
Chronic glomerulonephritis & 53 & $(18)$ \\
Hypertensive nephropathy & 25 & $(8)$ \\
Diabetic nephropathy & 147 & $(51)$ \\
Other/Unknown & & \\
General medical condition & 56 & $(19)$ \\
Diabetes & 73 & $(26)$ \\
Hepatitis & & \\
Current medication & 114 & $(40)$ \\
Antihypertensives & 70 & $(24)$ \\
Diuretics & 163 & $(57)$ \\
Calcium carbonate & 35 & $(12)$ \\
Antiplatelet agents & 119 & $(42)$ \\
Vitamins & 162 & $(57)$ \\
Others & 57 & $(20)$ \\
Smokers & & \\
\hline
\end{tabular}

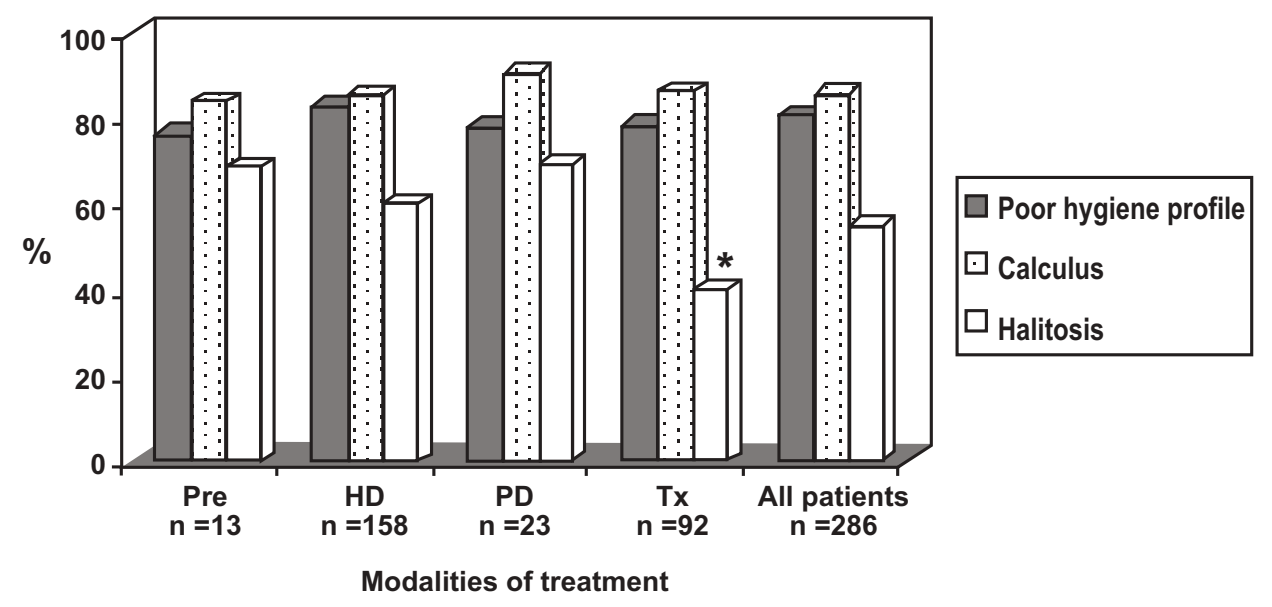

Pre: predialysis; HD: hemodialysis; PD: peritoneal dialysis; Tx: transplant.

${ }^{*}$ Prevalence of halitosis in transplant patients was significantly lower than the observed in HD, PD and Pre patients.

Figure 1. Prevalence of poor hygiene profile, halitosis and dental calculus in patients with chronic kidney disease. 
great majority of patients $(248 / 286)$ presented dental calculus (86.7\%) for all modalities of treatment (Figure 1). Halitosis was reported by $158 /$ 286 (55\%) patients. Transplant patients (Tx) reported less halitosis $(40.2 \%)(\mathrm{p}=0.004)$ when compared to groups Pre (69.2\%), HD (60.7\%), and PD (69.6\%) (Figure 1).

The DMF-T for the whole population was 20.6 The DMF-T for all forms of treatment is shown in Figure 2. There was a significant correlation between age and DMF-T $(r=0.21 ; p<0.0001)$. According to what was expected, CKD individuals with defective oral health presented a higher number of dental caries $(6.7 \pm 0.3)$ when compared to patients with good oral health condition (4.7 $\pm 0.6 ; p=0.005)$. The average of tooth decay was $5.4 \pm 4.4$, and $9.7 \pm 8.7$ teeth were missing.

\section{DisCUSSION AND CONCLUSION}

The rapidly increasing number of patients with CKD combined with the unacceptably high morbidity and mortality in patients receiving dialysis or a renal transplant points to an urgent understanding of the mechanisms responsible for the development of complications of CKD. From this point of view, the evaluation and promotion of oral health appears to be an important component of CKD care. It is necessary for the dental practitioner to thoroughly understand the special needs that arise from these patients ${ }^{15}$. This study was a retrospective and cross-sectional analysis that aimed to evaluate the oral health status in a large group of Brazilian patients followed in a clinic specialized in dental aspects of CKD. The main findings of this study were that CKD patients present defective general oral health status and a high prevalence of dental calculus, factors that may predispose these patients to oral diseases.

Patients with CKD present several relevant oral health problems, including uremic halitus, dry mouth, and taste and salivary alterations ${ }^{16-18}$. It has also been observed increased prevalence of caries, gingivitis, dental mobility, tooth loss, and dental calculus in this population ${ }^{7}$. General oral health condition was considered defective for most patients of the study population and correlated to dental caries. Indeed, previous studies have suggested that oral hygiene of hemodialysis patients is worse than that for the general population ${ }^{8,11,12}$. Bad hygiene may be explained on the basis of the chronic nature of the illness. Patients are concerned about their renal disease and tend to neglect preventive measures related to other health aspects. Renal dysfunction has been also associated with psychological implications. These patients experience the stress of complying with frustrating dietary restrictions that have been found to contribute to anxiety reactions or depression ${ }^{19,20}$.

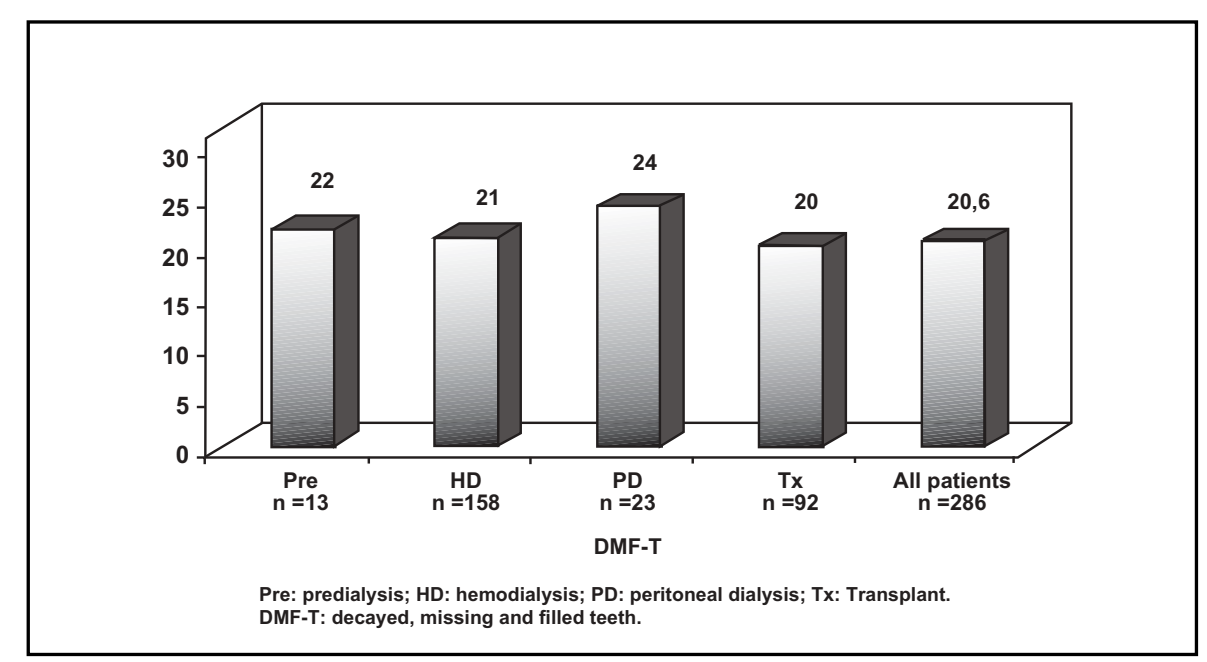

Figure 2. DMF-T index for the CKD patients according to the modality of treatment. 
The great majority of patients presented dental calculus. Indeed, in a study that analyzed the prevalence of calculus in a population from the same region and of similar age ${ }^{21}$ showed that the prevalence of calculus was $40 \%$, less than half the prevalence described in CKD patients. Dialysis patients may form calculus more rapidly than healthy individuals, possibly due to high salivary urea and phosphate levels ${ }^{22}$. Other important risk factors for the development of dental calculus are the ingestion of large quantities of calcium carbonate (used as a phosphate binder), hyperparathyroidism, and deficient hygiene $\mathrm{e}^{8,11,23}$. The impact of the high prevalence of calculus on periodontal disease remains to be investigated in future studies.

Halitosis can also result from poor oral health. Other causes of halitosis and uremic fetor are xerostomia and the presence of urease-splitting oral organisms, which metabolize urea (present in high levels in these patients) and thus elaborate ammonia $^{6}$. In our study, transplant patients reported less halitosis when compared to groups of patients with CKD before the transplant, possibly indicating that uremic toxin levels may be the main determinant of halitosis in the CKD population.

Dental caries is among the most common oral health problems all over the world. They occur in between 50 and $99 \%$ of people in most communities. The patients in the present study presented a DMF-T equal to 20.6, equivalent to that reported for the South population of Brazil (DMF-T = 20.6) ${ }^{24}$. Higher prevalence of caries has been reported in CKD patients ${ }^{25}$. However, a study 26 showed a low rate of caries in hemodialysis patients, what was thought to be related to a possible antibacterial effect of urea or increased

\section{REFERENCES}

1. Sarnak MJ, Levey as, Schoolwerth aC, Coresh J, Culeton B, Hamm LL et aL; American Heart Association Councils on Kidney in Cardiovascular Disease, High Blood Pressure Research, Clinical Cardiology, and Epidemiology and Prevention. Kidney disease as a risk factor for development of cardiovascular disease: a statement from the American Heart Association calculus. Although the DMF-T in the CKD patients was identical to the general population of the same sex and age, poor hygiene correlated to dental caries in the study population.

According to WHO, good health is a major resource for social, economic and personal development, and an important dimension of quality of life. Health promotion action aims at making these conditions favourable through advocacy for health ${ }^{27}$. Oral health could be explained as a status of complete normality of teeth and support structures in both morphological and functional ways and, also, of the perioral parts and structures related to mastication and maxillofacial complex. Especially in compromised individuals, like CKD patients, oral environment might be assisted in order to promote not only oral but general health. Since one of the major complications in CKD patients is sepsis, and knowing that infectious diseases in the oral cavity may act as foci for systemic diseases or injury in other sites of the body, oral health must be achieved and maintained during all the CKD patient treatment period $^{8}$.

Evaluated parameters suggest defective oral health status in chronic kidney disease patients undergoing different modalities of treatment. Supportive dental programs must be established in order to minimize pathogens influence, which may predispose to systemic complications.

\section{Acknowledgement}

This study was supported by grants from the Araucária Support Foundation for Scientific and Technological Development of Paraná and National Counsel of Technological and Scientific Development (CNPq).

Councils on Kidney in Cardiovascular Disease, High Blood Pressure Research, Clinical Cardiology, and Epidemiology and Prevention. Hypertension 2003; 42: 1050-65.

2. Pecoits-Filho R, Lindholm B, Stenvinkel P. The malnutrition, inflammation, and atherosclerosis (MIA) syndrome - the heart of the matter. Nephrol Dial Transplant 2002; 17: 28-31.

3. Stenvinkel P, Lindholm B, Heimburger O. Novel approaches in an integrated therapy of inflamma- 
tory-associated wasting in end-stage renal disease. Semin Dial 2004; 17: 505-15.

4. Gaul D, Berger E, Kaufman E. Pulp narrowing in renal end stage and transplanted patients. J Endod 1991; 17: 442-3.

5. Woodhead J, Nowak A, Crall J, Robilard J. Dental abnormalities in children with chronic renal failure. Pediatr Dent 1982; 4: 281-5.

6. KLaSSEN JT, KRAsKo BM. The dental health status of dialysis patients. J Can Dent Assoc 2002; 68: 34-8

7. LoCsey L, Alberth M, Mauks G. Dental management of chronic hemodialysis patients. Int Urol Nephrol 1986; 18: 211-3.

8. ATASSI F. Oral home care and the reasons for seeking dental care by individuals on renal dialysis. J Contemp Dent Pract 2002; 15: 31-41.

9. Durán I, ERDEMIR EO. Periodontal treatment needs of patients with renal disease receiving haemodialysis. Int Dent J 2004; 54: 274-8.

10. Rahman MM, Caglayan F, Rahman B. Periodontal health parameters in patients with chronic renal failure and renal transplants receiving immunosuppressive therapy. J Nihon Univ Sch Dent 1992; 34: 265-72.

11. Gavalda C, Bagan J, Sculy C, Silvestre F, Milin M, JIMÉNEZ Y. Renal hemodialysis patients: oral, salivary, dental and periodontal findings in 105 adult cases. Oral Dis 1999; 5: 299-302.

12. Naugle K, Darby ML, Bauman DB, Lneberger LT, Powers R. The oral health status of individuals on renal dialysis. Ann Periodontol 1998; 3: 197-205.

13. Marakogud I, Gursoy UK, Demirer S, Sezer H. Periodontal status of chronic renal failure patients receiving hemodialysis. Yonsei Med J 2003; 44: 648-52.

14. Joint WHO/FAO Expert Consultation on Diet, Nutrition and the Prevention of Chronic Diseases Diet, nutrition and the prevention of chronic diseases: report of a joint WHO/FAO expert consultation (WHO technical report series; 916).

15. Al-Wahadni A, Al-Omari MA. Dental diseases in Jordanian population on renal dialysis. Quintessence International 2003; 34: 343-7.
16. Kho HS, LeE SW, Chung SC, KIM YK. Oral manifestations and salivary flow rate, $\mathrm{pH}$, and buffer capacity in patients with end-stage renal disease undergoing hemodialysis. Oral Surg Oral Med Oral Pathol Oral Radiol Endod 1999; 88: 316-9.

17. Kao CH, Hsieh JF, Tsai SC, Ho YJ, Chang HR. Decreased salivary function in patients with endstage renal disease requiring hemodialysis. Am J Kidney Dis 2000; 36: 1110-4.

18. Kaya M, Cermik TF, Ustun F, Sen S, Berkarda S. Salivary function in patients with chronic renal failure undergoing hemodialysis. Ann Nucl Med 2002; 16: 117-20.

19. Stewart RS, Stewart RM. Neuropsychiatric aspects of chronic renal disease. Psychosomatics 1979; 20: 529-31.

20. Fricchione GL, Howanitz E, Jandorf L, Kroessier D, Zervas I, WozNICKI RM. Psychological adjustment to end-stage renal disease and the implications of denial. Psychosomatics 1992; 33: 85-91.

21. http://www.saude.se.gov.br/. Brasília, March, 2004.

22. EpSTeIN SR, Mandel I, Scopp IW. Salivary composition and calculus formation in patients undergoing hemodialysis. J Periodontol 1980; 51: 336-8.

23. Wong L, Sissons CH, Pearce EI, Cutress TW. Calcium phosphate deposition in human dental plaque microcosm biofilms induced by a ureolytic pH-rise procedure. Arch Oral Biol 2002; 47: 779-90.

24. http://www.saude.pr.gov.br/saudebucal/index.html

25. Bayraktar G, Kazancioglu R, Bozfakioglu S, Yildiz A, ARK E. Evaluation of salivary parameters and dental status in adult hemodialysis patients. Clin Nephrol 2004; 62: 380-3.

26. De Rossi SS, GLCK M. Dental considerations for the patient with renal disease receiving hemodialysis. J Am Dent Assoc 1996; 127: 211-9.

27. The Third edition of "Oral Health Surveys - Basic methods", Geneva 1987 (www.whocollab.od.mah.se/expl/orhsurvey.html). 